\title{
Functional Significance of Contextual Distribution: Discourse Particle $A R$ IN BANGLA
}

\author{
Soumya Sankar GHOSH \\ ghosh.soumya73@yahoo.com \\ Jadavpur University, India
}

\section{Arka BANERJEE}

banerjeesoumyo29@gmail.com

Jadavpur University, India

\author{
Samir KARMAKAR \\ samirkrmkr@yahoo.co.in \\ Jadavpur University, India
}

\begin{abstract}
This paper deals with Bangla indeclinable ar to explore its role in conversational discourse. In doing so, the paper provides a detail study about ar in the Bangla language. This, in turn, helps to conceptualize how the occurrences of ar motivate a conversation in a pragmatic domain, in particular. More specifically, multiple interpretations of ar pose a particular challenge to semantics and pragmatics, which can be taken care of through the incorporation of phonological context. Phonological context contains information about speaker's intention and speaker's approach to their utterance. The paper discusses several criteria, namely the traditional and polysemous nature, intonational pattern, evidentiality etc., which are crucial in determining its role in structuring a conversation.
\end{abstract}

Keywords: particle ar; intonation; evidentiality

\section{Povzetek}

Članek se osredotoča na nesklonljivi ar v bengalščini in proučuje njegovo vlogo $v$ govorjenem diskurzu ter s tem ponudi podrobno analizo o njegovi uporabi. Takšen pristop posledično omogoča tudi zaključke v obratni smeri in sicer o tem, kako pojavnost izraza ar na pragmatični ravni spodbuja pogovor. Številnost njegovih interpretacij predstavlja izziv tako v semantiki kot v pragmatiki, kar pa je moč poenostaviti z upoštevanjem fonološkega konteksta. Slednji namreč vsebuje informacije o govorčevih namerah in govorčevemu odnosu do izrečenega. Avtor tako razpravlja o fonoloških kriterijih kot so tradicionalna in večpomenska narava izreke, intonacijski vzorci, dokazljivost idr., ki so odločilni pri ugotavljanju njegove vloge v pogovoru.

Ključne besede: členek ar; intonacija; dokazljivost 


\section{Introduction}

This paper seeks to investigate the role of Bangla indeclinable ar in a discourse emphasizing particularly on its usage pattern at the utterance level. A brief survey of its usage in Bangla discourse reveals that ar functions in two different ways, i.e. (i) it can either occur as a conjunctive indeclinable, or (ii) as a non-conjunctive indeclinable. This non-conjunctive indeclinable, in the level of utterance, contains multiple senses depending on its contextual behavior. Therefore, the objective of this research paper is to disambiguate the various senses of $a r$ with a special reference to the contexts of its use. For further elaboration, please consider the following examples:
(1) রাম
আর রহিম
আসবে
ram
ar rohim
as-b-e
Ram-NOM INDL Rahim-NOM come-FUT-3
'Ram and Rahim will come.'
(2) রাম আর আসবে না
ram ar as-b-e na
Ram-NOM INDL come-FUT-3 NEG
'Ram will never come.'
(3) আর বছরে রাম এসেছিল

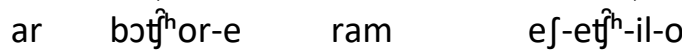
INDL year-Loctemp Ram-NOM come-PRF-PST-3
'Ram came in the previous year.'

It is evident from these examples that the indeclinable ar has different roles in all its occurrences. As in (1) it occurs as a conjunctive particle having the sense of 'and', additionally its scope is restricted within the NP (e.g. ram ar rohim). As a conjunctive particle it is connected with two NPs (ram and rohim). Contrarily, in (3) ar is modifying the following NP (bot thor-e) and carries the sense of 'previous': being modified with ar the complex NP (e.g. $\operatorname{ar}$ bot $t^{\text {h}}$ or-e) appears VP internally and finally moves to the sentence initial position. In (2) ar means 'never', and it appears within the scope of VP (e.g. ram ar afbe na).

To understand the way ar brings different colors of interpretation simply by overriding the truth conditional content of the utterance within which it is embedded, this paper will concentrate primarily on the constructions like (2) and (3).

\section{Research Question}

While dealing with ar, this paper will engage itself in analyzing the role of $a r$ in a communicative context. In particular, the pragmatic function and evidential nature of this particle in a conversational discourse will be explored. To attain these goals stated 
above the discussion is distributed in following major sections: Section 3 will provide a short overview of Bangla language and thereafter Section 4 will contain a discussion on how ar is dealt with in traditional Bangla grammar. This is further augmented with a discussion on the polysemic nature of ar. Subsequently, in Section 5 an effort has been taken to integrate the traditional findings with the phonological ones to explore how communicative intention is crucial in determining the way meaning construing capacity of ar do vary from one context to another.

\section{Bangla: An Overview}

Bengali, also known by its endonym Bangla, is an Indo-European language mainly spoken in eastern South-Asia. It is the national language of Bangladesh and the official language of India, spoken mainly in West Bengal and parts of Assam, Bihar, Jharkhand, Mizoram Tripura North Western Burma and Andaman and Nicobar Islands. With over 250 million speakers it is the seventh most spoken native language in the world.

Following Gordon (2005), Khan (2008) points out that Grierson's (1928) survey of Bangla dialects is still used as the basic classification of the language's variants. Grierson divides the Bangla language in two branches, i.e. Eastern and Western. It is important to mention here that this division does not follow any national or geographic boundary. The paper summarize the said branches in the following manner.

\section{Western Branch}

a. Central Bangla

i. In Indian West Bengal: Nadia (Standard Bengali), Kolkata, Haora, Tamluk, Medinipur, Murshidabad, Barddhaman

ii. In Bangladesh: Kushtia

b. Northern Bangla

i. In Indian West Bengal: East Malda, Koch Bihar

ii. In Bangladesh: Rajshahi, Dinajpur, Bogra, Pabna

c. Western Bangla

i. In Indian West Bengal: Kharia Thar, Mal Paharia, Manbhum

ii. In Indian Bihar: Saraki

d. Southwestern Bangla

\section{Eastern Branch}

a. Eastern Bangla

i. In Bangladesh: Dhaka, southeastern Faridpur, Mymensingh, Comilla, Bakerganj, Sylhet, Hajong, Sandwip Island 
ii. In Indian Assam: Cachar

b. East-Central Bangla

i. In Bangladesh: Jessore, Khulna, Faridpur

c. Southeastern Bangla

i. In Bangladesh: Noakhali, Chittagong, Chakma, Tangchangya

ii. In Myanmar: Sittwe

d. Rajbanshi

i. In Bangladesh: Rangpur

ii. In Indian West Bengal: Siripuria, Jalpaiguri, Bahe

iii. In Indian Assam: Goalpara

Depending on this division Khan (2008) further points out that the dialects not only differs in syntactic level but a major difference is also observable in phonological and morphological level. The distinction between oral and nasal vowel, $/ \mathrm{s} /$ and $/ \mathrm{s} /, / \mathrm{\lambda} /$ and $/ \mathrm{r} /$, vowel rounding harmony, voicing harmony are some of the noteworthy differences (Chatterjee, 1939; Grierson, 1928). Thus, even though the speakers of all dialects are familiar with the standard form (as for India it is the 'Kolkata Standard Bengali' and for Bangladesh it is the 'Bangladeshi Standard Bengali') regional dialect's influence on this standardize form is significant. Having said this in the next section the paper will focus on the behavior of ar in detail. In doing this, the paper will concentrate on the 'Kolkata Standard Bengali' in terms of data and for the analysis part.

\section{Indeclinable ar in Bangla}

Traditionally, ar is classified as an indeclinable mainly because of being insensitive to the declension. Its significance lies with its capacity to change the overall sense of an utterance. Compare (4) with (5): the example (4) says nothing specific about the span of time for which the articulation holds true. In other words, it works in an indefinite manner leaving the scope of Ram's coming back in some future time. Whereas (5) holds true for a longer period of time: in fact depending of the context sometimes it may indicate that 'Ram will never come'. More formally, the latter one indicates that the coming of Ram will never hold true for all future time.
(4) রাম
আসবে
নा
ram
as-b-e
na
Ram-NOM come-FUT-3 NEG
'Ram will not come.' 


\begin{tabular}{|c|c|c|c|c|}
\hline (5) & রাম & আর & আসবে & না \\
\hline & ram & ar & as-b-e & na \\
\hline & $\begin{array}{l}\text { Ram-NOM } \\
\text { 'Ram will n }\end{array}$ & INDL & $\begin{array}{l}\text { come-FUT-3 } \\
\text { again ' }\end{array}$ & NEC \\
\hline
\end{tabular}

Both of these two utterances form a minimal pair in virtue of (not-) having ar in the utterance body. From their respected literal translation it is also clear that whatever difference they do posses in their meaning is due to the (non-)appearance of ar: in fact appearance of ar remains extremely crucial in implicating a particular type of inference under the precedence of a pretext as is illustrated below:
(6) (রামের যা মনের অবস্থা) রাম আর আসবে না (ram-er dźa mon-er sbost ${ }^{\text {ha) }}$ ) ram ar af-b-e na ram-GEN PRT mind-GEN situation Ram-NOM INDL come-FUT-3 NEG '(The state of mind in which Ram is now,) Ram will not come again.'
(7) রাম আর কখনোই আসবে না ram ar kok honoi as-b-e na Ram-NOM INDL ever come-FUT-3 NEG 'Ram will not ever come again.'

Being a implicature of (6), (7) satisfies the feature of conversational implicature namely defeasibility, non-detachability, calculability, non-conventionality. With the substitution of an utterance containing no ar in (6), a different implication is licensed.

\begin{tabular}{|c|c|c|c|c|c|c|}
\hline $\begin{array}{l}\text { (রামের } \\
\text { (ram-er } \\
\text { ram-GEN }\end{array}$ & $\begin{array}{l}\text { या } \\
\text { dźa } \\
\text { PRT }\end{array}$ & $\begin{array}{l}\text { মনের } \\
\text { mon-er } \\
\text { mind-GEN }\end{array}$ & $\begin{array}{l}\text { অবস্থা) } \\
\text { obostha) } \\
\text { situation }\end{array}$ & $\begin{array}{l}\text { রাম } \\
\text { ram } \\
\text { Ram-NOM }\end{array}$ & $\begin{array}{l}\text { আসবে } \\
\text { as-b-e } \\
\text { come-FUT-3 }\end{array}$ & $\begin{array}{l}\text { ना } \\
\text { na } \\
\text { NEG }\end{array}$ \\
\hline
\end{tabular}

Therefore, (4) and (5) as the members of a minimal pair reflect contrastive distribution resulting into a kind of paradigmatic arrangement.

\subsection{Nature of $a r$}

As it has been stated earlier, this paper mainly focuses on the non-conjunctive ar, and this section in particular will concentrate on how ar In Bangla behaves as a discourse particle. Unlike the other particles such as to, na, particle ar does not bring any kind of a semantic change by its presence in the initial, medial, or the final situation of an utterance. As shown below: 
(9) রাম আর আসবে না

ram ar as-b-e na

Ram-NOM PRT come-FUT-3 NEG

'Ram will not come again.'

(10) রাম আসবে ন আর

ram as-b-e na ar

Ram-NOM come-FUT-3 NEG PRT

'Ram will not come again.'

(11) আর রাম আসবে ন ন

ar ram as-b-e na

PRT Ram-NOM come-FUT- NEG

'Ram will not come again.'

However this is not the case with other Bangla particles to and na. Consider the examples of (12)-(15).
(12) রাম
তো আসবে
ram
to as-b-e
Ram-NOM PRT come-FUT-3
'Ram will come.'
(13) রাম না আসবে
ram na as-b-e
Ram-NOM PRT come-FUT-3
'Ram will come.'

The appearance of to and na as modifiers of the preceding noun in the subject position of (12)-(13) plays a crucial role in emphasizing the respective assertions unambiguously. Therefore, phonological cues are not significant in interpreting these utterances. Contrariwise (14)-(15) need phonological cues to get interpreted unambiguously. In the absence of the phonological context, as is the case here, each of them can be interpreted either as an assertion or as a question.
(14) রাম
আসবে
তো
ram
as-b-e
to
Ram-NOM come-FUT-3 PRT

'Ram will come./Will Ram come?'

$\begin{array}{lll}\text { (15) রাম } & \text { আসবে } & \text { না } \\ \text { ram } & \text { af-b-e } & \text { na } \\ \text { Ram-NOM } & \text { come-FUT-3 } & \text { NEG }\end{array}$

'Ram will not come./Will Ram not come?' 
Chatterjee (1939) points out ar as one of the members of the fundamental indeclinable class $^{1}$ in Bangla. In sentential level it can co-occur with other particles. Consider the following:

(16) রাম তো আর আসবে না

ram to ar as-b-e na

Ram-NOM PRT PRT come-FUT-3 NEG

'Ram will not come again.'

(17) রাম ন ন আর আসবে না

ram na ar as-b-e na

Ram-NOM PRT PRT come-FUT-3 NEG

'Ram will not come again.'

(18) রাম কি আর আসবে না?

ram ki ar as-b-e na

Ram-NOM PRT PRT come-FUT-3 NEG

'Ram will not come again?'

In (16)-(18) ar is used in all examples to emphasize the predicate of the utterance but it is also interesting to observe the role of other particles in these utterances. In (16) the speaker's intention was to add a pragmatic force both to the subject and predicate, as the occurrence of to after the subject and occurrence of ar before the predicate emphasize subject and predicate respectively. By doing this speaker wants to imply that 'it is Ram who will not come again'. Similarly, in (17) the insertion of na induces politeness to the whole information and in (18) the question particle ki adds a notion of polarity to the utterance.

\subsection{Polysemous Nature of ar}

The discussion about the nature of ar instigates the paper to focus on another unique feature. In some situations, the meaning construing capacity of ar, both in the sentence and utterance level, largely depends on the words with which it co-occurs. As a consequence, in these case ar functions not as a particle but as a grammatical category with which it co-locates. Such as the following:

(19) আর একবার এ এস

ar æk-bar ef-o

ADJ one-time come-PRS-2

'Come once again.'

\footnotetext{
${ }^{1}$ Chatterjee (1939) identifies $n a, b a, k i, a r$, to, as a fundamental indeclinable in Bangla. In the utterance level these indeclinable, having the nature of particle, works as a functional category. Therefore, we can form a class, containing these particles as members of it.
} 
(20) রাম

আর কিছু বলল না?

ram ar kith ${ }^{\mathrm{h}} \mathrm{u}$ bol-l-o na?

Ram-NOM ADJ some say-PST-3 NEG

'Ram didn't say anything else?'

(21) ইস্কুলে

পৌঁছলাম আর

বৃষ্টি আরম্ভ হল

iskul-e põuth ${ }^{h}(0)-I-a m$ ar

bristi

aromb $^{\text {ho }}$ ho-l-o

school-Loc

reach-PST-1

CON

rain

begin

be-PST-3

'As soon as I reached the school rain started.'

(22)

$\begin{array}{llll}\text { তুমি } & \text { বল } & \text { আর না } & \text { বল } \\ \text { tumi } & \text { bol- o } & \text { ar } & \text { na }\end{array}$

It is not hard to show from these examples (19)-(23) that ar in discourse creates various types of meanings depending on its use. In the example (19) ar carries a sense of 'again' that makes the speaker to request the hearer to come one another time. In the next example, (20), ar indicates the sense of 'more' and the speaker by saying this utterance expressing his expectation in an emphasizing manner. ar in the example (21) adds information of time having 'as-soon-as' sense. Similarly example (22) and (23) also contains two different meanings of ar i.e. a sense of 'or' and a sense of 'another'. It is to be important to mention over here that unlike the other examples ar in (21) functions not as a particle rather as a conjunctive indeclinable.

These examples, which are mentioned above, establish our line of argument that the meaning construing force of ar is very much dependent on the neighboring words. That's why the resulted utterances are interpreted in the distinct ways. As in the case of (19) the incorporation of ar with the quantifier ækbar brings the sense of 'again' in the sentence. In (20) ar is generating the sense of 'more' as it appears after the pronoun ki $t^{h} u$. In rest of the examples, ar is forming the senses like 'as-soon-as', 'or', and 'another' by following the mentioned claim. This line of argument can further be cemented by three examples from the above- (3), (19) and (23). In all these cases ar occurs initially but creates three different interpretations depending on its different cooccurrences, with the sense of 'year', 'once' and 'person'.

A line of syntactic thought will specify that the occurrence of ar in utterance initial position will not project ar as a particle rather as different lexical categories regardless of its non-conjunctive nature. As in (19), (20) and (23) it functions like an adjective, in (21) as a conjunctive and in (22) as an indeclinable. 


\section{Discussion}

What follows in, therefore, is an emerging necessity to explore the significance of $a r$ in an utterance in inducing a particular illocutionary force. To address this newly evolved concern one need to consider the phonological make up of an utterance because the appearance of a particle in an utterance influence the meaning in two distinct ways: (a) It influence the meaning of the utterance in terms of those pragmatic behaviors which are pertinent from the viewpoint of the discrete segmental appearance of it. This is discussed in detail in Section 4, and, (b) beyond its discrete reality it also participates in the non-discrete supra-segmental make up of the utterance. Though the syntactic semantic and pragmatic behavior of the particle is discussed in existing literature on particles, very few of them in any true sense tries to explore the way communicative intention is captured through the characteristic interactions holding between the segmental and supra-segmental layers of linguistic representations. This is exactly the departure point from where the current investigation differs from the rest of the studies on particles.

In the level of prosodic hierarchy, an utterance is denoted as an Intonational Phrase (henceforth IP) which is comprised of Phonological Phrases (henceforth PP or P). A PP is further decomposed into the Prosodic Word (henceforth, Pwd), containing information about the supra-segmental aspects associated with the lexical words (lex) $)^{2}$. Furthermore function words ${ }^{3}$ (henceforth Fnc) categorized as either Prosodic Word or as a Prosodic clitic ${ }^{4}$ (henceforth Pcl) (Selkirk, 2003).

In the phonological phrase the pitch accents are tones - high $(H)$ or low $(L)$ - that gets linked to stressed syllables, which is formally represented as $\mathrm{H}^{*}$ and $\mathrm{L}^{*}$. At the boundary level, both for the phonological phrase and intonational phrase, the phrase accent is identified as Phonological phrase boundary or $T_{p}$ and Intonational phrase boundary or $T_{1}$ (Hayes \& Lahiri, 1991). Having said this, the intonational pattern of the sentence (4) can be represented in Figure 1:

\footnotetext{
${ }^{2}$ Selkerk (2003) talked about two structures in the level of utterance- i) S-structure, ii) P-structure. S-structure contains the lexical words (Lex) whereas the P-structure contains the sequence of Prosodic words (Pwd) in phonological representation.

${ }^{3}$ Function words (Fnc) are the members of a class in which membership is largely fixed, such as in the cases with determiners, prepositions, conjunctions and particles. Lexical words (Lex), on the other hand, constitute the open class expressions having the unlimited numbers as the new items are continually being added.
}

${ }^{4}$ Prosodic clitics ( $\mathrm{Pcl}$ ) are those morpho-syntactic words which are not itself a Pwd. 


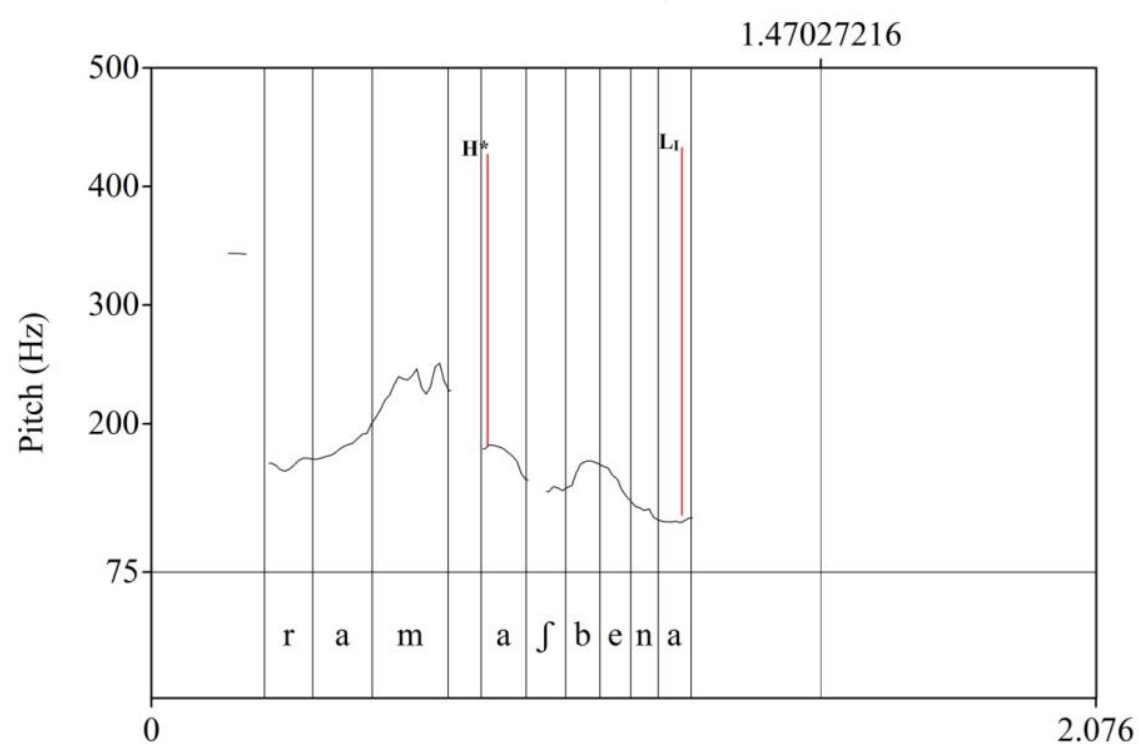

Time (s)

Figure 1: Pitch Pattern of Example (4)

Figure 1 shows that the initial syllable of a word often carries the stress marker as the syllable $a \int$ gets the stress and it also receives a high pitch accent $\left(\mathrm{H}^{*}\right)$. Additionally, the graph falls down around the final syllable of the I- phrase boundary $\left(L_{1}\right)$ just after the high pitch accent $\left(\mathrm{H}^{*}\right)$. The corresponding metrical grid representation is given in Figure 2 to show the distribution of the stresses over the utterance:

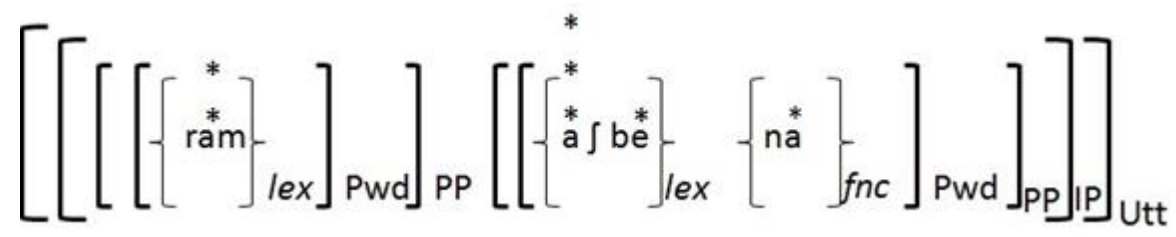

Figure 2: Metrical Grid of Example (4)

In Figure 2, ram and asbe na are the two P-phrase that constitutes IP/Utt. Note that in a neutral situation like this, the declarative sentence the right most P-phrase within the I-phrase receives the main prominence as the I-phrase stress rule assigns stress to the rightmost P-phrase of the I-phrase. In this metrical grid, na functions as a prosodic clitic, more precisely as an internal clitic ${ }^{5}$ and because of this it further adds extra stress to the left most non-clitic word (Hayes \& Lahiri, 1991).

\footnotetext{
${ }^{5}$ Internal clitic is another branch of prosodic clitic which is dominated by the same Pwd that on the other hand dominates its sister lexical word lex
} 
The insertion of ar in the utterance does not alter the meaning of the sentence rather adds a higher degree of negativity to it. This higher degree of negativity can only be achieved through the performance of some inferential task as it is already discussed towards the beginning of Section 4. Nearly, similar situation can be grasped through (24) and (25) from different perspective.
(24) সুশীল
আসবে?
sufil
as-b-e
Susil-NOM come-FUT-3
'Will Susil come?'
(25) সুশীল আর আসবে?
sufil ar as-b-e
Susil-NOM PRT come-FUT-3
'Will Susil come again?'

A close look on these two examples will indicate that, in the examples (24) and (25), the speaker is giving the license to the hearer to draw the inference that the speaker is in doubt about Susil's coming. Additionally, a careful analysis of these two examples do vary from each other in terms of their respective implicational capacities: (24) implicates that the speaker is concerned about Susil's coming in a (future) span of time of which the lower bound is the utterance time associated with it. More explicitly, Susil's coming could be either true or false in the presupposed span of time; as a consequence (24) will not implicate the falsity of Susil's coming for all future time. Here in this case speaker's psychological state is severely restricted by a temporal constraint in virtue of not having a hidden sense of 'never'. Contrariwise in (25) Susil's coming is in doubt for all future time. In other words, speaker's psychological state presupposes the presence of 'never' in the underlying representation. In fact, speaker is asking the hearer to confirm whether Susil will ever come. Due to its characteristic implicational pattern, (25) can be further augmented with the following lexicalized context as its pretext:

(26) সে দিনের বাজে ব্যবহারের পর তোমার কী
se din-er badze byabohar-er por tomar ki
that day-GEN bad behavior-GEN then you-NOM Q-PRT
সুশীল think
susil Mর আসবে?
Susil-NOM PRT come-FUT-3
'Do you think that Susil will come again after the behaviour you have shown to
him on the day of the accident?'

In the domain of conversation the particle ar captures more emotional coloring through the intonational pattern. Consider the following: 
$\begin{array}{rlll}\text { (27) Speaker 1: } & \text { দেখবে সবাই } & \text { আসবে } \\ & \text { dekh-b-e Jobai } & \text { aJ-b-e } \\ & \text { see-FUT-3 all } & \text { come-FUT-3 } \\ & \text { 'Don't worry, everyone will come.' }\end{array}$

Speaker 2: (সবাই এলেও) রাম আর আসবে না

(Sobai ele-o) ram ar as-b-e na

(all come-COND-EMP) Ram-NOM PRT come-FUT-3 NEG

'(Although everyone will come) Ram will not come again.'

(28) Speaker 1: রাম আর আসবে ন

ram ar as-b-e na

Ram-NOM PRT come-FUT-3 NEG

'Ram will not come again?'

Speaker 2: না

na

no

'No.'

In (27) the speaker 2's incorporation of ar in his reply against speaker 1's question establishes the fact that the speaker 2 is more or less confirm that the person called 'Ram' will never come. On the other hand in (28) the situation is little different. Here, the speaker uses ar in his utterance as a negative polarity particle by making a change in the intonation. In situations like these two mentioned in (27) and (28), then, the question arises how the distinctive intonations associated with the utterances are selected. A little attention will reveal the fact that the selection of intonation patterns are not bound to the selection of the discrete lexical unites of the utterances rather they are bound to the context of the communication.

The intonation pattern of the example mentioned in (27), as evident in Figure 4, does not show much change compare to the Figure 1.The interesting fact over here is that the ar as a clitic particle brings ram under narrow focus situation as per the illustration of Figure 3:

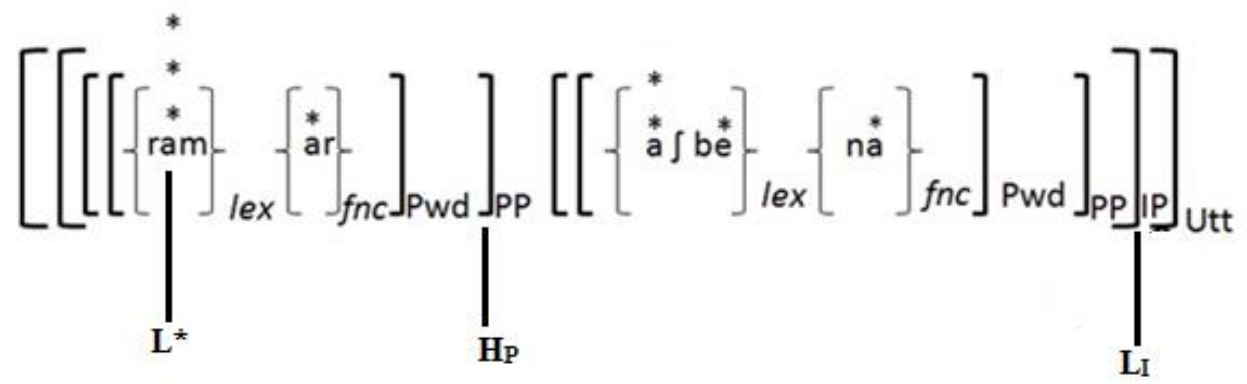

Figure 3: Metrical Grid of Speaker_2's Utterance in Example (27) 
The Figure 3, under the narrow focus situation, there is a low pitch accent on the syllable ram and for this reason the phrase ram-ar receives a high tone in the P-phrase boundary $\left(H_{P}\right)$, the pitch map will show this fact more on an elaborate manner.

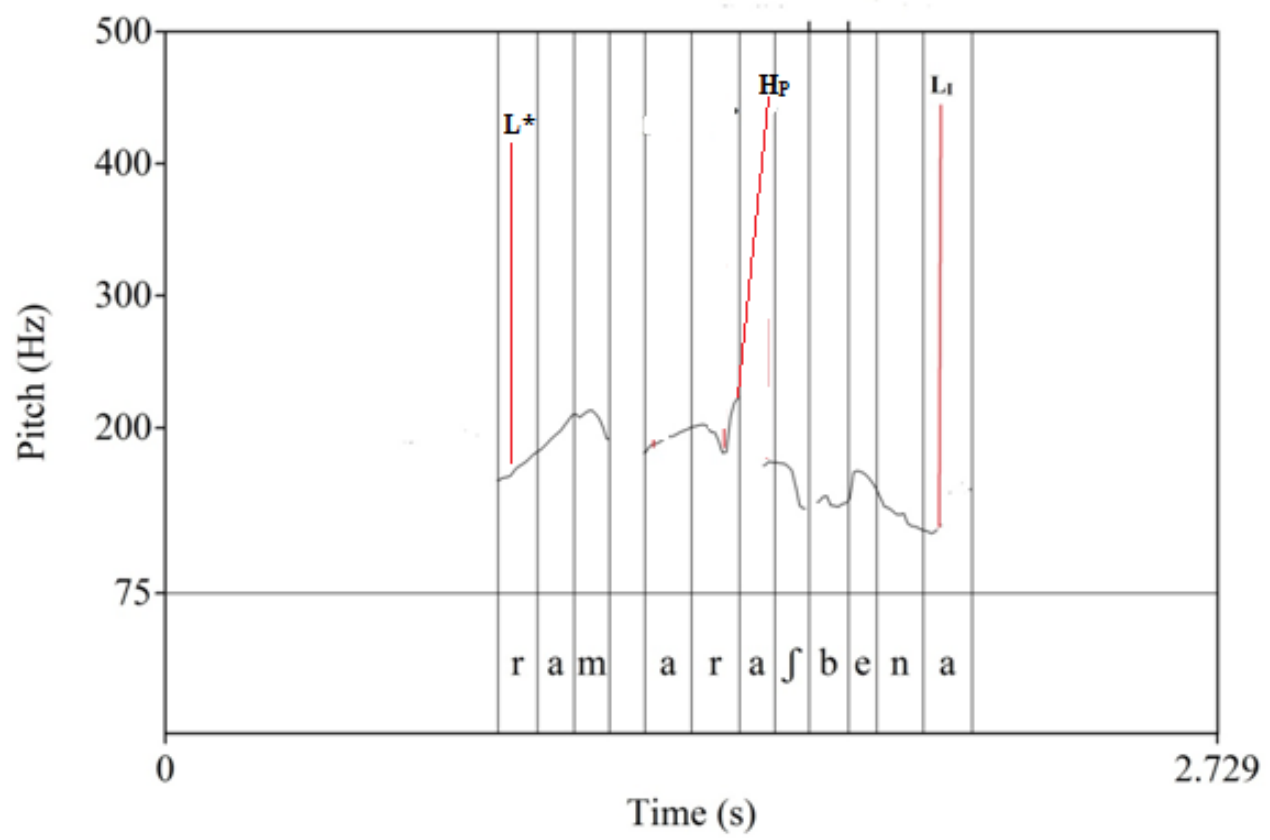

Figure 4: Pitch Pattern of Speaker_2's Utterance in Example (27)

It is important to note here that ar not only appears as a clitic particle but additionally as an internal clitic. It further implies that lex-fnc combination displaying a phonological behavior identical to that of Pwd which is constituted of a single lex alone. In Bangla, this particular combination is possible only because it fulfills the criterion- the left edge of any Pwd is required to coincide with the left edge of a Foot. (McCarthy \& Prince, 1993)

(29) Align (Pwd, L; Ft, L)

The transformation of this declarative sentence to an interrogative sentence through the change in intonation brings change not only in the metrical grid but also in the pitch map. 


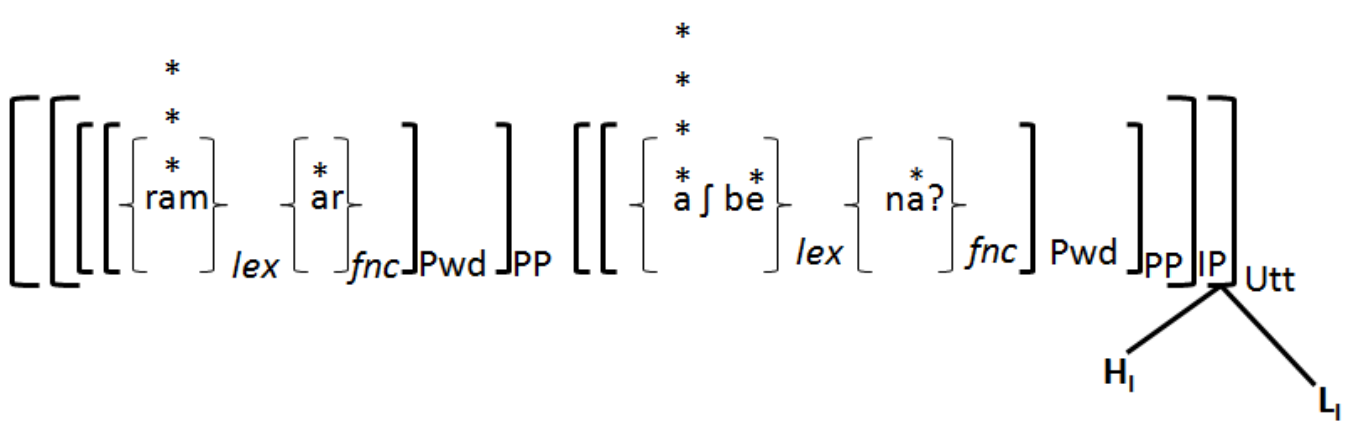

Figure 5: Metrical Grid of Speaker_1's Utterance in Example (28)

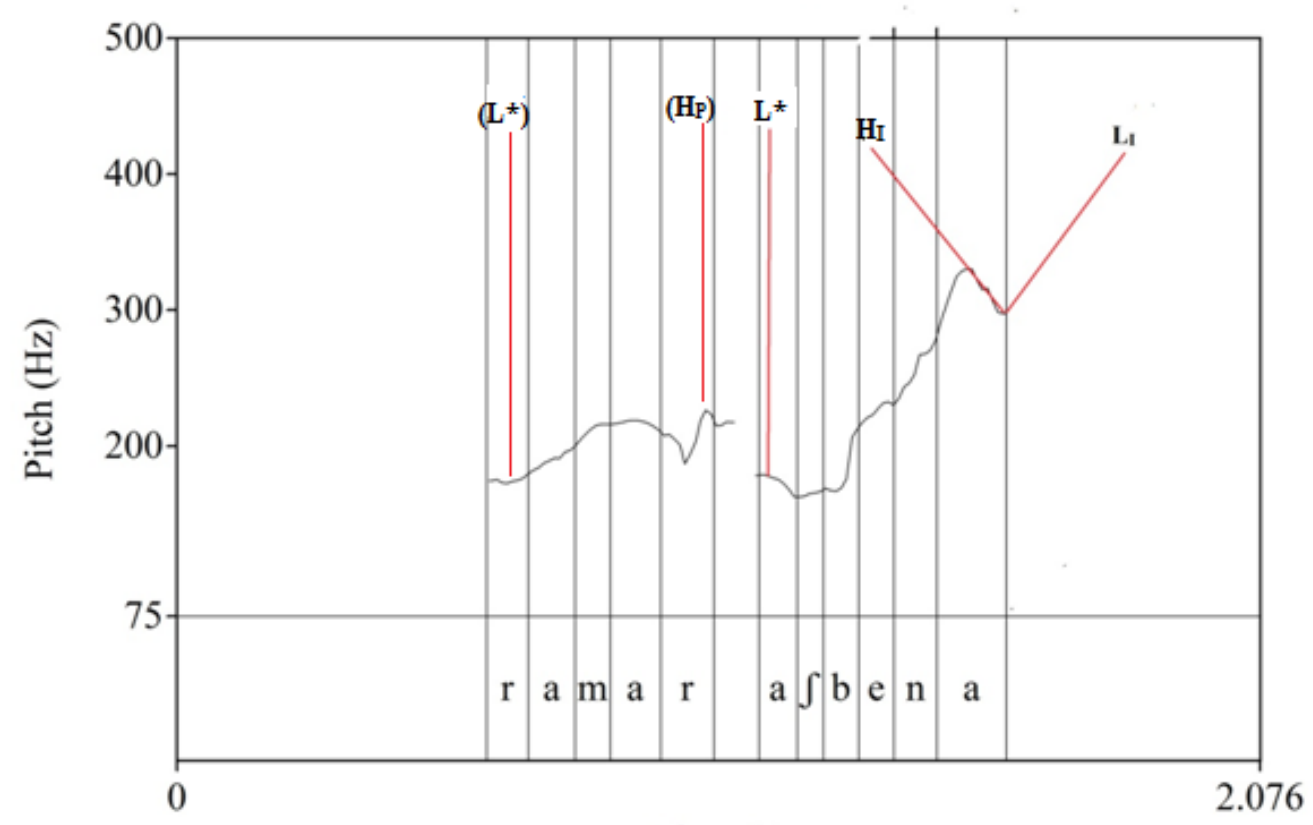

Time (s)

Figure 6: Pitch Pattern of Speaker_1's Utterance in Example (28)

The utterance, as a question, has its narrow focus on afbe na, the first syllable of this word, i.e. $a$, gets the main stress of the utterance. In the yes/no situation, the main stressed syllable often gets the low pitch and then this pitch rises smoothly to the last syllable $n a$, and afterwards it falls again, as is shown in Figure 6 . The presence of $H_{1}$ and $L_{1}$ sequence in the pitch map indicates that in the IP boundary, high peak is followed by a final low value.

The paper has already argued that the intonation is very much context dependent phenomenon. Keeping this thing in mind, we can also say that the particle ar can be occurred not only as a clitic particle but also as a focus particle in the utterance like ram ar a fbe na. Jackendoff (1972), in a similar occasion once argued that if a P-phrase comes in the focus position of an utterance $(U)$, the highest stress in $U$ will be on the syllable 
of that P-phrase. Thus the pragmatic domain of the focus is also its phonological domain. As a consequence the focus is defined in the following way:

(30) Focus: If $F$ is a Focus and DF is its domain then the highest prominence in DF will be within $\mathrm{F}$.

In the conversational discourse the domain of focus (DF) is defined as a sector from which the scope of the focus can be determined. This domain is both phonologically and semantically relevant. This pragmatic-phonological interface can be illustrated in Figure 7 and Figure 8:
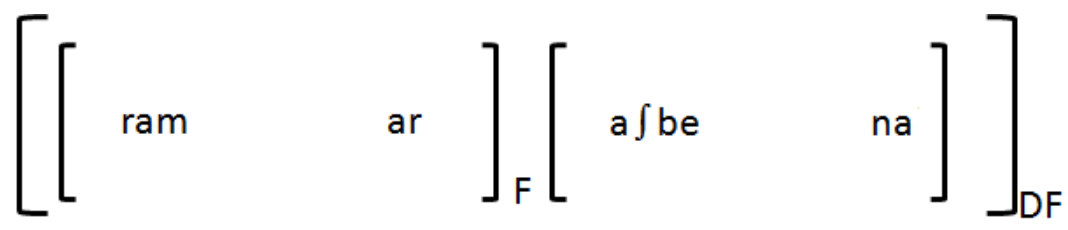

Figure 7: Phonology Pragmatics Interface with Focused Subject Containing Discourse Particle

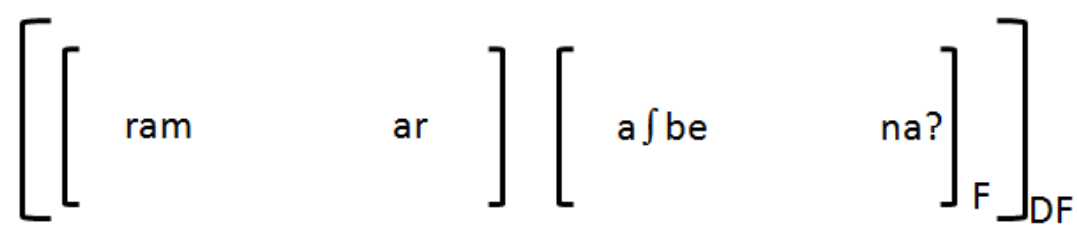

Figure 8: Phonology Pragmatics Interface with Non-Focused Subject Containing Discourse Particle

Figure 7 suggests that ar as a clitic particle emphasizes the constituents with which it is attached to, as in this case ram is stressed. Due to this, the entire clause being a domain of focus, selects ram-ar as a focus constituent. On the contrary the interrogative utterance in Figure 8 implies the fact that the speaker is uttering this question out of disbelief. Thus in the entire focus domain a fbe na gets the relative prominence compare to ram-ar and as a consequence it comes in the focus part.

\section{Evidential Nature of ar}

The above discussion ensures the fact that ar not only generates speaker's intention but it also marks the source and reliability of their knowledge behind a particular assertion. It specifies the source of evidence on which statements are based, the degrees of precision, probability and expectations. So, in simple words we can say that, ar as an evidential shows what kind of justification for a factual claim is available to the person making the claim. In order to grasp the evidentiality in a better way, the machinery of Grice's theory becomes important as it explains not only what is 
conversationally implied but also in what is said. Therefore by applying the maxims of Quality to the utterances $(P)$, we have mentioned above, can be reinterpreted as (a) the speaker believes that ' $P$ ', and also (b) the speaker has adequate evidence of ' $P$ '.

In the level of utterance this evidential nature is not only expressed through the linguistic items (in this paper it is ar) but also through the extra linguistic elements such as intonation. As in (27) and (28) the sentence ram ar asbe na is uttered from two different intonational pattern, i.e. (27) in declarative tone and (28) in the tone of question. It implies that in (27) on the base of some evidence speaker believes that Ram will not come whereas in (28) the speaker was not sure about Ram's arrival for this reason he was trying to confirm the fact. Thus, it is visible if the speaker is asserting/claiming/declaring that $\mathrm{P},(\mathrm{s})$ he must believe that $\mathrm{P}$; if the speaker is suggesting/guessing/questioning that $\mathrm{P},(\mathrm{s})$ he must believe that there is not sufficient reason to believe that $P$, which is weakest degree of commitment (Bach \& Harnish 1979).

To sum up, we can say that in Bangla discourse ar plays a very significant role in construing the pragmatic meaning. It further answers the question on 'what constitutes the knowledge of language' and how this knowledge is put to use. A more thorough research on this line and a comparative study of some Bangla discourse particles will help us to build the structure of the conversation in a more concrete manner.

\section{References}

Bayer, J., Dasgupta, P., Mukhopadhyay, S., \& Ghosh, R. (2014, February 06-08). Functional Structure and the Bangla Discourse Particle to. Retrieved from http://ling.unikonstanz.de/pages/StructureUtterance/web/Publications \& Talks files/Ba yer Dasgupta MukhopadhyayGhosh SALA.pdf

Bach, K., \& Harnish, R. N. (1979). Linguistic Communication and Speech Actss. MIT. Press Cambridge. Mass.

Chatterjee, S. K., (1939). Bhasa-Prokash Bangla Byakaron. Rupa Publication India Limited.

Dastidar, R. G., \& Mukhopadhyay, S. (2013). Utterance Discourse and Meaning: A Pragmatic Journey with the Bangla Discourse Particle/na/. In: Mining Intelligence and Knowledge Exploration (pp. 814-822). Springer International Publishing.

Gordon, R. G., Jr. (ed.) (2005). Ethnologue: Languages of the World, Fifteenth edition. Dallas, Tex: SIL International. Online version: http://www.ethnologue.com/.

Grierson, A. (1928). Linguistic Survey of India. Calcutta, British India. Available online: http://joao-roiz.jp/LSI/

Hayes, B., \& Lahiri, A. (1991). Bengali Intonational Phonology. Natural Language \& Linguistic Theory, 47-96. Springer International Publishing.

Ifantidou, E. (2001). Evidentials and Relevance. John Benjamins Publishing Company.

Jackendoff, R. S. (1972). Semantic Interpretation in Generative Grammar. MIT Press, Cambridge, Mass. 
Khan, S. (2008). Intonational Phonology and Focus Prosody in Bengali. PhD thesis, University of California, Los Angeles.

McCarthy, J., \& Prince, A. (1993). Generalized Alignment. In G. Booij \& J. van Marle (Eds.), Yearbook of Morphology 1993. Dordrech: Kluwer.

McHugh, B. (1990). Cyclicity in the Phrasal Phonology of Kivunjo Chaga. Ph.D. dissertation, UCLA.

Selkirk, E. (2003). The Prosodic Structure of Function Words. In J. McCarthy, ed. Optimality Theory in Phonology:A Reader. Blackwell Publishing. 